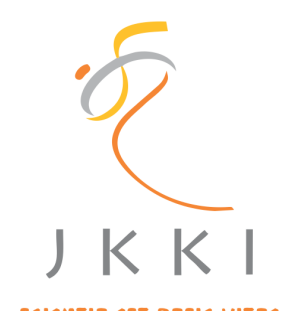

SCIEHTIA EST BASIC VITAE

\section{Jurnal Kedokteran dan Kesehatan Indonesia}

\author{
Indonesian Journal of Medicine and Health
}

Journal homepage: https://journal.uii.ac.id/JKKI

\title{
Adjuvant chemotherapy-associated febrile neutropenia in a patient with breast malignancy: A case report
}

\author{
Esravila Ariya Wibisono*1, Onggo Wiliyanto ${ }^{1}$ \\ ${ }^{1}$ Panti Wilasa Citarum Hospital, Semarang, Indonesia
}

Case Report

\begin{tabular}{|c|c|}
\hline & ABSTRACT \\
\hline ARTICLE INFO & Adjuvant chemotherapy has been widely applied in patients with breast \\
\hline $\begin{array}{l}\text { Keywords: } \\
\text { febrile neutropenia, } \\
\text { chemotherapy-associated, } \\
\text { breast malignancy }\end{array}$ & $\begin{array}{l}\text { mallgnancy after surgery to prevent lts recurrence and to improve } \\
\text { survival comprehensively. Febrile neutropenia is one of the most life- } \\
\text { threatening chemotherapy-associated toxicities. A } 66 \text { years old woman } \\
\text { came to an emergency department of a secondary healthcare facility }\end{array}$ \\
\hline $\begin{array}{l}\text { *Corresponding author: } \\
\text { esravila@gmail.com }\end{array}$ & $\begin{array}{l}\text { one week after her final chemotherapy with dose regimen of docetaxel } \\
\text { and epirubicin, followed by having nausea, vomitus, and general fatigue }\end{array}$ \\
\hline DOI : 10.20885/JKKI.Vol11.Iss2.art15 & with a fever of $38.2^{\circ} \mathrm{C}$. Based on her medical record, she had experienced \\
\hline $\begin{array}{l}\text { History: } \\
\text { Received: November 12, } 2019 \\
\text { Accepted: August 19, } 2020 \\
\text { Online: August } 31,2020\end{array}$ & $\begin{array}{l}\text { breast malignancy for almost two years and had already conducted } \\
\text { mastectomy three months after her diagnosis. Her leukocyte number } \\
\text { was only } 300 \text { cells per } \mathrm{mm}^{3} \text {, with } 23 \% \text { neutrophil, hypoalbuminemia, }\end{array}$ \\
\hline $\begin{array}{l}\text { Copyright @2020 Authors. } \\
\text { This is an open access article } \\
\text { distributed under the terms } \\
\text { of the Creative Commons At- } \\
\text { tribution-NonCommercial } 4.0 \\
\text { International Licence (http:// } \\
\text { creativecommons.org/licences/ } \\
\text { by-nc/4.0/). }\end{array}$ & $\begin{array}{l}\text { and hypokalaemia. She was then treated in an internal ward and was } \\
\text { given intravenous ceftazidime, fluid, granulocyte colony-stimulating } \\
\text { factor, albumin transfusion, intravenous potassium replacement, and } \\
\text { symptomatic medication. After two days of inpatient care, she was referred } \\
\text { to an oncology team in a tertiary healthcare facility. Febrile neutropenia } \\
\text { is considered as a fever with a low neutrophil number as a result of } \\
\text { bone marrow suppression. The neutrophil plays an essential role as the } \\
\text { body's first line of defence. This condition could make the patient more } \\
\text { vulnerable to infections. The Patient was given broad-spectrum antibiotics } \\
\text { and typically hospitalized to allow close monitoring until the neutropenia } \\
\text { was resolved. Febrile neutropenia possesses a serious threat to patients } \\
\text { with breast malignancy who are on cytotoxic chemotherapy. Urgent full } \\
\text { blood count and immediate broad-spectrum antibiotic administration are } \\
\text { significant to reduce morbidity and mortality. }\end{array}$ \\
\hline
\end{tabular}

$\overline{\text { Kemoterapi adjuvan telah banyak digunakan pada pasien dengan keganasan payudara setelah operasi }}$ untuk mencegah kekambuhan penyakit dan meningkatkan kualitas kelangsungan hidup pasien secara menyeluruh. Demam neutropenia merupakan salah satu contoh toksisitas terkait dengan kemoterapi yang paling mematikan. Seorang wanita berusia 66 tahun datang ke instalasi gawat darurat di sebuah fasilitas kesehatan sekunder dengan keluhan demam $38.2^{\circ} \mathrm{C}$. Selain demam, pasien juga mengeluhkan kelemahan umum, mual, dan muntah. Riwayat keganasan payudara terjadi sejak dua tahun yang lalu (sudah dilakukan operasi mastektomi). Satu minggu yang lalu pasien mendapatkan rejimen dosis kemoterapi terakhir yang terdiri dari docetaxel dan epirubicin. Pemeriksaan darah rutin ditemukan jumlah leukosit 300 sel per $\mathrm{mm}^{3}$ dengan 23\% neutrofil dari total leukosit, hipoalbuminemia, dan hipokalemia. pasien dirawat di bangsal penyakit dalam dan diberikan ceftazidime intravena, terapi cairan, faktor stimulasi koloni granulosit, tranfusi albumin, pengganti kalium intravena, dan obat simptomatik. Setelah dua hari perawatan inap, pasien dirujuk ke tim onkologi yang merawatnya di fasilitas kesehatan tersier. Demam 
neutropenia merupakan suatu kondisi demam dengan jumlah neutrofil tubuh yang rendah sebagai akibat dari penekanan sumsum tulang. Oleh karena neutrofil memainkan peran penting sebagai garis pertahanan pertama tubuh, kondisi ini membuat pasien lebih rentan terhadap infeksi. Pasien dalam mondisi ini diberikan antibiotik spektrum luas dan biasanya dirawat di rumah sakit untuk pemantauan ketat sampai neutropenia teratasi. Demam neutropenia merupakan ancaman serius untuk pasien yang menjalani kemoterapi. Pemeriksaan hitung darah lengkap dan pemberian antibiotik spektrum luas segera sangatlah penting untuk mengurangi mortalitas dan morbiditas.

\section{INTRODUCTION}

In the last decade, treatments of breast malignancy have advanced significantly. ${ }^{1}$ During its early year, a surgical mastectomy had been a gold standard to treat women with breast malignancy. ${ }^{2}$ Nevertheless, a prognosis of those treated with only surgery has not been favourable, and then chemotherapy has been incorporated with surgery to treat patients with breast malignancy. ${ }^{3}$ Patients with malignancy are often administered with several courses of systemic chemotherapy during their treatment. ${ }^{4}$ These chemotherapy agents are often cytotoxic and associated with some adverse effects such as febrile neutropenia, infusion reaction, and general fatigue. ${ }^{3,5}$

Chemotherapy-induced neutropenia is a life-threatening condition when the neutrophil drops are below normal that can increase morbidity, mortality, and financial cost in a cancer treatment. ${ }^{6}$ Risks of increasing febrile neutropenia, which refers to occurrence of a fever during a period of significant neutropenia, depend on a degree and duration of chemotherapy-induced neutropenia followed by some other factors like age, comorbidity, and serum albumin levels. ${ }^{7,8} \mathrm{~A}$ cancer patient with febrile neutropenia is immunocompromised with higher risks of infections, and this is a medical oncology emergency. ${ }^{1,5,8,9}$

Despite significant improvements in prevention and treatment, febrile neutropenia remains one of the most feared complications of chemotherapy. ${ }^{1,2}$ According to some reports, estimated cumulative risks of neutropenia range between $21-24 \%$ following adjuvant chemotherapy and often require hospitalization. ${ }^{3}$ Rates of bacterial resistance to widely used antibacterial agents are increasing, while only a small number of newer antimicrobial agents have been available in recent years that may make this condition harder to treat. ${ }^{9}$ Though the number is decreased, even with an appropriate treatment, the febrile neutropenia still contributes to an average mortality risk about $5 \%{ }^{1,10}$

\section{CASE DESCRIPTION}

A 66 years old woman treated at an emergency department of a secondary healthcare facility came with a main complaint of fever. She had complained about having a fever for thelastseven days after her final dose of chemotherapy. Before the final chemotherapy dose, she had denied having similar symptoms. Initially, her complaint started with a mild fever that got higher until the patient shivered even though she had already used a blanket. The fever slightly decreased after the patient had consumed over-the-counter antipyretics, yet consequently, it always rose again.

Beside the fever, she also complained about having escalating nausea for the last week until she vomited a white-yellowish liquid for several times. She also mentioned that she experienced general fatigue with decreased appetite. She denied having cough, shortness of breath, chest pain, haemoptysis, pain while breathing, dysuria, having wound in the body, and joint pain or swelling.

Two years before coming to the emergency department, she had a history of painless lumps in her right breast, which was examined at an oncologist's office. It was found that the lumps were malignant, and finally a modified radical mastectomy was conducted at a tertiary healthcare facility three months after the diagnosis. A pathology report was taken from her right breast tissue that she had an invasive carcinoma of no special type grade II with 3 centimetres in diameter. Her 
immunohistochemistry estrogen receptor (ER) staining result was positive, although less than $20 \%$ with low-to-moderate intensity. No regional lymph nodes metastases were found. A chemotherapy was administrated in another tertiary healthcare facility from the same oncologist with regimen per course doses adjusted to her BMI. Docetaxel and epirubicin were given every three weeks for six cycles.

Vital signs in the emergency department were as follow: patient's awareness was compos mentis with a blood pressure of $120 / 60 \mathrm{mmHg}$; heart rate of 130 beats regularly per minute, respiration rate was 20 times per minute; and temperature was $38.5^{\circ}$ Celsius. From the physical examination, it was found that her conjunctiva was slightly anaemic, and her palms and feet were mildly swollen and slightly pale.

Table 1: Abnormal results of auxiliary examination

\begin{tabular}{cc}
\hline $\begin{array}{c}\text { Auxiliary } \\
\text { examination }\end{array}$ & $\begin{array}{c}\text { Result } \\
\text { (reference value) }\end{array}$ \\
\hline Blood routine tests & \\
White blood cells & $0.3 \times 10^{9} / \mathrm{L}(4.0-10.4)$ \\
Haemoglobin & $9.5 \mathrm{~g} / \mathrm{dL}(12.1-15.1)$ \\
Red blood cells & $3.2 \times 10^{12} / \mathrm{L}(3.8-5.2)$ \\
Segmented neutrophil & $23 \%(50-70)$ \\
Lymphocytes & $58 \%(25-40)$ \\
Monocytes & $16 \%(2-8)$ \\
Electrolyte serum & \\
Natrium & $131.7 \mathrm{mmol} / \mathrm{L}(135-147)$ \\
Potassium & $2.8 \mathrm{mmol} / \mathrm{L}(3.5-5.0)$ \\
Serum albumin & $2.5 \mathrm{~g} / \mathrm{dL}(3.4-5.0)$ \\
\hline
\end{tabular}

She was immediately administered by 2 grams of intravenous ceftazidime and then admitted to an internal medicine ward for further monitoring and for improving general condition. During her hospitalization, she was given $500 \mathrm{mg}$ of paracetamol tablet per 6 hours to control her fever, 2 grams of intravenous ceftazidime per 12 hours, $100 \mathrm{ml}$ of $20 \%$ albumin infusion, 300 micrograms of filgrastim (rh-G-CSF) injection, two cycles of $25 \mathrm{mEq}$ intravenous potassium chloride, 20 milligrams of intravenous furosemide per 24 hours, and 4 milligrams of ondansetron injection if needed. After two days of inpatient care with a stable condition, she was referred to her oncology team in a tertiary healthcare facility.

\section{DISCUSSION}

Definitions of febrile neutropenia vary in several guidelines, but this condition is a combination of fever and a very low concentration of neutrophil in blood laboratory examination. ${ }^{1}$ Fever is defined as a condition when human body temperature is $>38^{\circ} \mathrm{C}$ for two consecutive readings in 2 hours, or it also can be defined as an oral temperature of $>38.3^{\circ} \mathrm{C} .{ }^{5,9}$ It should be noted that antipyretic medication used for analgesia or anti-inflammation properties, such as steroids, non-steroidal anti-inflammatory agents, and acetaminophens, may obscure the fever. ${ }^{9}$ Neutropenia is defined as a condition with an absolute neutrophil number of $<1.0 \times 10^{9} / \mathrm{L}$, which is severely lower than the standard reference value. ${ }^{1,2,10}$

Febrile neutropenia is a result of myelosuppression, which is a common adverse effect of chemotherapy. ${ }^{10}$ Chemotherapy agents, which are cytotoxic, can suppress both cancer cells and healthy cells like skin, mucous membrane, and bone marrow. ${ }^{5}$ In addition, it can also induce haematological toxicity that affects haemoglobin levels, host defence mechanisms, and blood clotting mechanisms. ${ }^{5,7}$ This toxic effect may occur in administration of single or combination of chemotherapy agents including but not limited to cyclophosphamide, vinblastine, docetaxel, cisplatin, carboplatin, epirubicin, and fluorouracil. ${ }^{6}$ A study concluded that a sequential setting of epirubicin and docetaxel is usually well tolerated. ${ }^{11}$ Patients with solid malignancy receiving chemotherapy every three weeks have the most significant neutropenia risk from day 7 to day 14 after the last dose. ${ }^{10}$

The neutrophil is a specific type of leukocytes (white blood cells) that play an essential role as the human body's first line of defence mechanism. It usually makes up about $40-60 \%$ of all white 
blood cells and protects against infectious agents. Infections may be resulted from transmission of an infectious agent between hosts or from commensal organisms that live in the body that generally does not cause illness because its immune system keeps away from invading. ${ }^{8}$

All patients with neutropenia lasting for seven days or fewer days are regarded as standard risks, while patients with an estimated duration of neutropenia for at least eight days are regarded as high risks with caution to a more complicated course of a febrile episode. ${ }^{9}$ Risk assessments can also be calculated by using the Multinational Association of Supportive Care in Cancer (MASCC) febrile neutropenia risk index criteria. ${ }^{2}$ Identification of risk factors for patients with febrile neutropenia is significant for safe management of chemotherapy-induced neutropenia. ${ }^{4}$ Febrile neutropenia patients with high risks for infection-associated complications usually have prognostic factors that are predictive of substandard clinical outcomes such as prolonged days ( $>10$ days), profound neutropenia $(<100 / \mu l)$, age $>65$ years old, and uncontrolled primary diseases. ${ }^{4,9}$ Apart from those factors, inadequate nutritional status, impaired renal and hepatic functions, prolonged steroid therapies, haematological malignancy, absence of hematopoietic colony-stimulating factor supports, histories of having a previous episode of febrile neutropenia, and presence of comorbidities are some other risk factors that need to be considered. ${ }^{1,10}$

Diagnostic measurement at the first fever in neutropenic patients aim to rule out noninfectious causes of fever, identify a clinical focus and causative pathogens, and assess patient's inflammatory response severity. ${ }^{9}$ An initial assessment for the patient is clinical, started by examining the patient's medical records and the patient's vital signs including consciousness levels, respiration rates, blood pressures, and temperatures. ${ }^{7}$ A detailed anamnesis should be taken, including the chemotherapy given, prior prophylactic antibiotics or G-CSF, concomitant steroid usage, presence of allergies, and recent surgical procedures. ${ }^{2}$ Full physical examination should be conducted, and auxiliary tests require complete blood count, C-reactive protein, renal and liver function, glucose, serum electrolyte, calcium, albumin, and chest X-ray. ${ }^{7}$

The first administration of therapy in patients with febrile neutropenia should be given within 1 hour from the hospital admission. ${ }^{2}$ Several guidelines, including The National Chemotherapy Advisory Group (NCAG) and The United Kingdom National Guideline, stated that all patients must receive intravenous broad-spectrum empirical antibiotics (doorto-needle) immediately without awaiting results of microbiology examination..$^{4,5,9,10}$ Delaying in antibiotic administration is associated with significantly longer hospital stay and increasing mortality. ${ }^{2}$

Roles of empirical antibiotics to reduce mortality and morbidity of patients with febrile neutropenia has long been recognized. ${ }^{1}$ In about $50 \%$ of patients, the antibiotic therapy will remain empirical with piperacillin/tazobactam, imipenem, meropenem, cefepime, and ceftazidime as first-line empirical antibacterial monotherapy options. ${ }^{9}$ A meta-analysis comparing monotherapy (anti- cephalosporin) and combined therapy found that both are equivalently effective., ${ }^{2,9}$ Patients, who are rapidly improved on intravenous antibiotics and are afebrile, hemodynamically stable, and no longer neutropenic, can switch to an oral antibiotic regimen. ${ }^{1,12}$

Treatment or prophylaxis with GranulocyteColony Stimulating Factor (G-CSF) is suggested to be given febrile neutropenic patients with high risks of infection who is clinically septic or hypotensive or have organ dysfunctions. ${ }^{5,13,14}$ It is not recommended for routine uses in clinical practices. ${ }^{9,14}$ G-CSF can decrease duration of neutropenia, fever, and length of hospitalization although these benefits are modest and mortality rates are unaffected. ${ }^{13,15}$ There are few side effects with its administration, and bone pain that usually can be relieved with analgesics is the most common. ${ }^{2,15}$ 


\section{CONCLUSION}

Febrile neutropenia is a medical emergency and constitutes a severe threat to patients with breast malignancy on cytotoxic chemotherapy due to elevated risks of infections. Urgent full blood count and immediate broad-spectrum antibiotic administration are significant to reduce morbidity and mortality in febrile neutropenia.

\section{CONFLICT OF INTEREST}

The authors have none to declare.

\section{ACKNOWLEDGEMENT}

The authors have none to declare.

\section{REFERENCES}

1. Kar M, Rakesh R. Indian guidelines for febrile neutropenia. 2002;3-6.

2. Klastersky J, de Naurois J, Rolston K, Rapoport B, Maschmeyer G, Aapro M, et al. Management of febrile neutropaenia: ESMO clinical practice guidelines. Annals of Oncology. 2016;27(Supplement 5):v111-8.

3. Wang Z, Chen JQ, Liu JL, Qin XG. Serious neutropenia following neoadjuvant chemotherapy for locally advanced breast cancer: A case report. Oncology Letters. 2016;11(2):1597-9.

4. Hashiguchi Y, Kasai M, Fukuda T, Ichimura T, Yasui T, Sumi T. Chemotherapy-induced neutropenia and febrile neutropenia in patients with gynecologic malignancy. Anticancer Drugs. 2015;26(10):1054-60.

5. Mugada V, Ramineni H, Padala D. 5-Fluorouracil induced severe febrile neutropenia and death. Journal of Young Pharmacists. 2017;9(1):133-4.

6. Nayak BSK. Case report: Febrile neutropenia in a patient with carcinoma of larynx. Journal of Medical Science And clinical Research. 2018;6(11):325-7.

7. Cameron D. Management of chemotherapy-associated febrile neutropenia. British Journal of Cancer . 2009;101(S1):S18-22.

8. Patel K, West H. Febrile neutropenia. JAMA Oncology. 2017;3(12):1751.

9. Heinz WJ, Buchheidt D, Christopeit M, von
Lilienfeld-Toal M, Cornely OA, Einsele $\mathrm{H}$, et al. Diagnosis and empirical treatment of fever of unknown origin (FUO) in adult neutropenic patients: Guidelines of the infectious diseases working party (AGIHO) of the German society of hematology and medical oncology (DGHO). Annals of Hematology. 2017;96(11):1775-92.

10. NaikJD, Sathiyaseelan SRK,Vasudev NS. Easily missed?: Febrile neutropenia. The British Medical Journal. 2011;342(7788):103.

11. Hirano A, Shimizu T, Watanabe O, Kinoshita J, Kimura K, Kamimura M, et al. Epirubicin and cyclophosphamide followed by docetaxel as primary systemic chemotherapy in locally advanced breast cancer. Anticancer Research. 2008;28(6 B):4137-42.

12. Vidal L, Ben dor I, Paul M, Eliakim-Raz N, Pokroy E, Soares-Weiser K, et al. Oral versus intravenous antibiotic treatment for febrile neutropenia in cancer patients. Cochrane Database Systematic Review. 2013;2013(10).

13. Cooper KL, Madan J, Whyte S, Stevenson MD, Akehurst RL. Granulocyte colony-stimulating factors for febrile neutropenia prophylaxis following chemotherapy: Systematic review and meta-analysis. BMC Cancer. 2011;11.

14. Bennett CL, Djulbegovic B, Norris LAB, Armitage JO. Colony-stimulating factors for febrile neutropenia during cancer therapy. The New England Journal of Medicine. 2013;368(12):1131-9.

15. Mhaskar R, Clark OAC, Lyman G, Engel Ayer Botrel T, Morganti Paladini L, Djulbegovic B. Colony-stimulating factors for chemotherapy-induced febrile neutropenia. Cochrane Database Systematic Review. 2014;2014(10). 